\title{
As enciclopédias de Michel Foucault
}

\author{
The Michel Foucault's Encyclopedias
}

\author{
Jean Dyêgo Gomes Soares \\ Doutor em Filosofia \\ Pontificia Universidade Católica do Rio de Janeiro [PUC-Rio] | CNPq
}

\section{RESUMO}

Enciclopédia não está entre os termos mais conhecidos de Michel Foucault. Todavia, ao olhar com atenção para algumas ocorrências desse termo ao longo de sua carreira, com uma especial ênfase aos anos de I960 e I970, algo se revela ao leitor atento. $\mathrm{O}$ intuito desse texto é discernir esse termo no vocabulário foucaultiano, mostrando sua dupla face. Se por um lado, Foucault se refere tecnicamente à Enciclopédia editada por Denis Diderot e Jean D'Alembert; por outro, ele recorre ao termo sugerindo outra prática que não simplesmente elabora um memorial de nossos saberes, mas ultrapassa essa fronteira na direção do que ele chamará de heterotópico. No primeiro momento, o caráter crítico da abordagem levará a consideraçóes sobre os limites do projeto enciclopédico, e as consequências práticas das políticas de memória e esquecimento que ele implica. Num segundo momento, a partir de fontes importantes como Nietzsche, Freud e Marx, compreenderemos as possibilidades de uma nova dobra na história das técnicas de interpretar, em busca de uma ressignificaçấo foucaultiana das enciclopédias.

\section{PALAVRAS-CHAVE}

Interpretação; Enciclopédia; História e Filosofia.

\begin{abstract}
Encyclopedia is not among the most know terms of Michel Foucault. However, something appears to a careful reader when he/she looks to some occurrences of this term in his work, with a special emphasis in 60 's and 70 's of 2oth century. The goal of this paper is to discern encyclopedia into foucauldian vocabulary, showing its double face. If, in one side, Foucault refers technically to Diderot and D'Alembert's Encyclopedia; in the other, he appeals to the same term to suggest another practice which is not simply elaborate a memorial of our "savoirs", but surpass this frontier in a direction of heterotopias, as he suggests. In the first moment of this work, the critical approach show how he scrutinizes the limits of the encyclopedical project, as well the practical consequences to politics of memory and forgetfulness which it implies. In the second, visiting important sources as Nietzsche, Freud and Marx, Foucault allows us to comprehend better the possibilities of a new turning into the history of interpretation techniques, seeking a particular ressignification of encyclopedia.
\end{abstract}

\section{KEY WORDS}

Interpretation; Encyclopedia; History and Philosophy. 


\section{Uma enciclopédia}

O sentido mais usual de enciclopédia refere-se à tradição que herda dos philosophes franceses a empresa de fazer a história através do acúmulo e justaposição de conhecimentos. Encontramos algumas referências desse primeiro sentido em alguns trabalhos de Michel Foucault, expostas a seguir.

A primeira delas está em "A pesquisa científica e a psicologia”, escrito de juventude, no qual Foucault discute os paradoxos envolvidos pela pesquisa em psicologia e, notavelmente, sua relação com a verdade e a filosofia. A citação a seguir se insere em um contexto que demarca a transformaçáo do campo das disciplinas psicológicas. Elas deixam de ser um saber em sentido amplo para se dedicarem à pesquisa sobre mecanismos que governam a mente. $\mathrm{O}$ autor sugere o desaparecimento de um tipo de saber ligado à memória, enquanto processo de acumulação de pensamentos em um ciclo fechado, dando lugar a uma ciência mais histórica, assentada em práticas de pesquisa, cujo caminho abre outras possibilidades. Dito isso, entendemos um pouco melhor sua sugestão de que:

A passagem da Enciclopédia para a pesquisa constitui sem dúvida um dos acontecimentos culturais mais importantes de nossa história. Não nos cabe discutir o lugar e o papel de uma psicologia sem um saber cuja pretensáo seria, de pleno direito, enciclopédica. O único problema que nos concerne é saber o que pode significar agora a psicologia como pesquisa, uma vez que a psicologia foi completamente transformada em pesquisa ( $D E \mathrm{I}, \mathrm{p} . \mathrm{I} 55)$.

O que gostaríamos de notar nessa passagem não se refere ao conteúdo específico do texto, mas sim à primeira ocorrência do verbete "enciclopédia". Ocorrência ligada aqui a temas de interesse que o acompanharão ao longo da vida, a saber, o interesse por positividades " $p s i$ " para pensar a genealogia de nossos saberes, os limites históricos de suas práticas, bem como o interesse por momentos de ruptura. Um exemplo deste último ponto é exposto na citação e explorado na sequência do texto: na psicologia, mas não só, pôde-se notar a transição de um saber enciclopédico que funcionava pela acumulação contínua de conhecimentos em ciclo fechado para um processo que funciona através da dispersão de pesquisas cujos caminhos diversos constroem um espaço aberto e, muitas vezes, em litígio no campo em questão.

Algumas ocorrências do sentido de enciclopédia estão expostas em As palavras e as coisas. Ali, Foucault fala do projeto levado a cabo por pensadores como Denis Diderot e Jean D'Alembert que no século XVIII fizeram uma "enciclopédia 'das ciências e das artes”" ( $P C$, p. I2O) que não dependesse do encadeamento próprio aos conhecimentos expostos. Elaborada em ordem alfabética, ela almejava um estudo aprofundado do homem e de suas açôes, como sugere seu editor D'Alembert (20I5, p. 9I): "Os homens são o primeiro livro que um homem assim deve estudar para vencer”. É bastante interessante, portanto, a citação desse projeto no interior de uma 
arqueologia das ciências humanas, pois para o seu tempo, a Enciclopédia representou uma espécie de quadro geral, espelho que reflete estudos detidos sobre os saberes e representações da própria espécie, a ser fixado, um pouco como a imagem do pintor que representa a si e a sua corte. $\mathrm{O}$ que se deve estudar aparece no interior e no exterior da pintura: dentro da Enciclopédia como verbete e graças àquele que a escreve fora dela. Como sugere Souza (2015, p. 25, grifos nossos), "a primeira finalidade da Enciclopédia, no entender de seus editores, é preservar do esquecimento os conhecimentos humanos, guardar na memória o patrimônio que o gênero bumano produziu em sua história."

O interesse de Foucault ao citar rapidamente a Enciclopédia pode ganhar novas dimensóes se consideramos o caráter antropocêntrico e historicista desse projeto. A Enciclopédia situa o discurso em uma linha mediana na qual, segundo Foucault, "a ciência se emparelha à percepção, e a reflexão às imagens", ou seja, nas palavras, no discurso, "o que se imagina torna-se o que se sabe, e em contrapartida, o que se sabe torna-se o que se representa cotidianamente" ( $P C$, p. I2O). É através dessas representaçóes que, de pleno direito, os elementos de nossos saberes iluminam-se mutuamente. Isso a tal ponto que pensar as zonas de sombra se torna dispensável: o que não se encontra refletido nessa imagem humana ou perceptível aos sentidos, o que não é humano, não estando ao alcance de sua arte e ciência, não se encontra na memória construída pela Enciclopédia.

Em sentido semelhante, há uma ocorrência em entrevista dada no calor do verão de 1966, quando As palavras e as coisas desponta entre os livros mais vendidos do ano. Foucault fala de uma forma de pensamento náo dialética que vinha se formando cuja genealogia remonta à Friedrich Nietzsche, Martin Heidegger, Bertrand Russell, Ludwig Wittgenstein e Claude Lévi-Strauss, exemplos de pensadores heterogêneos entre si que, todavia, fogem à empresa enciclopédica. O que seria tal empresa? Nas palavras do autor:

Primeiramente, a Enciclopédia acumulava os conhecimentos e os justapunha. $\mathrm{O}$ pensamento atual deve definir isomorfismos entre os conhecimentos. Em segundo lugar, a Enciclopédia tinha como tarefa anular o não saber em proveito do saber, da luz. Nós, nós temos de compreender positivamente a relação constante que existe entre o não-saber e o saber, pois um não suprime o outro; eles estáo em relaçáo constante, eles se endossam um ao outro e só podem ser compreendidos entre si ( $D E$ I, p. 543).

Entre os diversos verbetes, o objetivo historicamente atribuído à empresa enciclopédica é o de construir o saber em sua positividade, permitir o seu abrigo, e protegêlo daquilo que foge ao controle, ou seja, do náo-saber. Aqueles pensadores seguem na contramão dessa tendência na medida em que compreendem a necessidade de refletir sobre o que é arbitrário, desafiador e resistente a formas catalogadas. Eles náo elidiam o não-saber, pois admitem sua existência e usufruem, cada um à sua maneira, dessa relação constante entre saber e não-saber. Foucault salientará a importância 
desse tema anos depois, em 1980 ao sugerir que "o tema nietzschiano da descontinuidade, do super-homem que seria completamente outro em relação ao homem, bem como, em Bataille, o tema das experiências limites através das quais o sujeito sai de si mesmo, se decompóe como sujeito, nos limites de sua própria impossibilidade, tiveram um valor essencial" ( $D E$ IV, p. 49). Foi a partir dessas experiências de transgressão dos limites do náo-saber, de uma outra relaçáo com o acaso e as descontinuidades que o impossível ganhou tangibilidade para os contemporâneos do autor.

Retomando o que se segue à passagem anterior, ela náo só é provocativa como esclarece a importância de se opor a um "enciclopedismo", cito:

Isso porque a filosofia passa atualmente por um tipo de zona de austeridade. É menos sedutor falar do saber e de seus isomorfismos do que da existência e de seu destino, menos consolador falar das relaçóes entre saber e não-saber do que falar da reconciliaçáo do homem consigo mesmo em uma iluminaçáo total. Mas, no final das contas, o papel da filosofia não é forçosamente adoçar a existência dos homens e lhes prometer algo como a felicidade ( $D E$ I, p. 543).

Foucault sugere aqui uma espécie de diagnóstico da própria filosofia de seu tempo quando diz que ela passava em 1966, antes, portanto, dos movimentos de maio de 1968, "por um tipo de zona de austeridade". Suas contraposiçôes sustentam a resposta final, e perceber alguns dos interlocutores aqui presentes pode colaborar. Falar dos saberes e de seus isomorfismos ou das relações entre saber e não-saber é algo que caracteriza não só o livro recém-publicado por ele, como algo presente por exemplo na Antropologia estrutural de Lévi-Strauss (2008, p. I8I et seq.) ou no pensamento das Investigaçóes Filosóficas de Wittgenstein (2009, \$150 et seq.). O papel da filosofia não é nem o de seduzir tampouco o de consolar através de temas como a existência, o destino, a reconciliação do homem consigo por meio de algo que o ilumine, como uma Enciclopédia. Na entrevista de 1980, anteriormente citada, Foucault chega a definir seu recurso a esses pensadores como "um tipo de saída" que ele havia encontrado para o hegelianismo e para a identidade filosófica do sujeito, que marcaram, por exemplo, o existencialismo na França de sua formação. É preciso admitir, porém que tais definiçóes negativas passam ao largo da promessa de felicidade que alguns desejam fazer soar da filosofia.

\section{Enciclopédias ambulantes}

Assim os ecos nietzscheanos não surpreendem aqui. À sua maneira, Foucault retoma e salienta os limites assinalados acerca do enciclopedismo. A Segunda consideração intempestiva consiste em um dos melhores exemplos nesse sentido. Um de seus principais objetivos consiste em mostrar os riscos de determinadas práticas históricas. Os tipos de história traçados ali (monumental, antiquária ou crítica), se praticadas temerariamente, alçadas como necessárias sempre, podem se mostrar desvantajosas para a vida e para o pensamento, pois o exagero de uma atitude enciclopédica - 
que tudo deseja fazer lembrar - pode prometer algo como a felicidade, exercendo, porém, o efeito contrário. Como sugere Nietzsche (2003, p. 9): "Em meio à menor como em meio à maior felicidade é sempre uma coisa que torna a felicidade o que ela é: o poder-esquecer, ou dito de outra maneira mais erudita, a faculdade de sentir a-historicamente durante a sua duraçáo". Toda a empreitada busca compreender até que ponto a história enquanto saber é útil para a vida, e até que ponto poder-esquecer, poder não-saber também o é: em resumo, em que medida ambos, saber e nãosaber, são necessários para a condução de uma vida potente. E nesse sentido, descontado o otimismo exagerado de Nietzsche em relação aos gregos, há uma comparação elucidativa entre a atitude destes e dos modernos em relação à história:

Aquele conhecido povozinho de um passado náo muito distante - tenho em vista aqui justamente os gregos - conservara teimosamente, no período de sua mais grandiosa força, um sentido a-histórico; se um homem sintonizado com o seu tempo precisasse retornar àquele mundo como que por um passe de mágica, ele talvez achasse os gregos muito "incultos", através do que certamente o segredo táo penosamente escondido da cultura moderna seria exposto publicamente ao ridículo: pois nós modernos não temos absolutamente nada que provenha de nós mesmos; somente na medida em que nos entulhamos e apinhamos com épocas, hábitos, artes, filosofias, religiōes, conhecimentos alheios, tornamo-nos dignos de consideração, a saber, enciclopédias ambulantes, com o que talvez um antigo heleno extraviado em nosso tempo nos dirigisse a palavra (Nietzsche, 2003, p. 34).

Há duas fábulas nesse trecho que se misturam. Na primeira, Nietzsche imagina um contemporâneo seu que retorna à Grécia helênica; fábula que se mistura a uma segunda, no fim da citação, em que um "antigo heleno" se extravia em "nosso tempo" para conversar. Nietzsche expóe e mistura duas "hipérboles" temporais. Ao longo do trecho, por um lado, ele salienta que a força dos gregos residia em ter uma relação com a história capaz de não elidir "um sentido a-histórico": ou seja, uma maneira de sentir que proviesse daquele mesmo tempo, que náo dependesse da consulta ao passado e ao arcabouço cultural de tempos imemoriais para a tomada de decisóes.

Força aqui deve ser entendida como força plástica que, para o autor, é a capacidade crescente que cada singularidade — um homem, um povo ou uma cultura tem de transformar e incorporar o que é estranho e passado, curando feridas, restabelecendo o perdido, reconstituindo por si mesmo as formas partidas (ibid., p. Io). É a força plástica a responsável por equilibrar a relação entre sentido histórico e o ahistórico, criando um esquecimento ativo capaz de incorporar elementos na maneira dessas singularidades perceberem, sem necessariamente desejar descobrir como tudo se deu em uma suposta origem histórica. Foucault sugere em "Nietzsche, a genealogia e a história", que "o sentido histórico está mais próximo da medicina do que da filosofia": ou seja, a pesquisa sobre tal sentido se dirige menos para servir ao filósofo em sua busca pelo nascimento da verdade e do valor; do que em direção ao 
conhecimento das "poçôes e contrapoções", das energias e humores, da história como uma "ciência dos remédios", expressão de Nietzsche em O viajante e sua sombra citada por Foucault ( $D E$ II, p. I49).

Assim, por outro lado, não surpreende a crítica de Nietzsche ao apego ao sentido histórico, típico de sua época, quando sugere que as "enciclopédias ambulantes" os homens modernos - são incapazes de esquecer, de lidar com o não-saber. Esse apego é manifesto na necessidade contínua de "entulhar-se" e "apinhar-se" com conhecimentos alheios que até os tornam dignos. Por isso, a personagem do nobre antigo heleno dirige-lhes a palavra, mas os tornam "ridículos" uma vez incapazes de esquecer a busca pelas origens e de desenvolver seu próprio sentido a-histórico, sua maneira particular de narrar. Usufruindo da imagem anterior, se a história é a ciência dos remédios, o apego excessivo à história resulta numa espécie de hipocondria. Menos do que nos aprofundar nessa comparação talvez exagerada entre gregos e modernos, é de interesse perceber aqui a crítica à empresa enciclopédica presente na Segunda consideração intempestiva. Nietzsche continua:

No entanto, nas enciclopédias todo o valor acha-se circunscrito ao que tem dentro, no conteúdo, não no que encontra fora, ou na encadernação e na capa. Desta feita, toda a cultura moderna é essencialmente interior; na parte de fora, o encadernador imprimiu algo assim como: "manual de cultura interior para bárbaros exteriores". Sim, esta oposiçáo entre dentro e fora torna o exterior ainda mais bárbaro do que precisaria ser, se um povo rude crescesse somente a partir de si e segundo suas necessidades grosseiras (Nietzsche, 2003, p. 34).

Essa citação pode ser lida como uma crítica ao projeto do esclarecimento, antecipando a crítica à razão moderna, característica de muitos trabalhos do século XX. Nietzsche chama a atenção para o fato de que não basta ter conteúdo interior não basta congregar saberes racional e enciclopedicamente numa interioridade, se exteriormente eles se manifestam como barbárie: a ascensão do fascismo, e principalmente do nazismo, pode servir aqui como um exemplo hiperbólico, mas eficaz. Um povo cuja força plástica faz crer que seu interior é o mais nobre desde a Grécia Arcaica, e manifesta sua suposta superioridade através do extermínio de milhares de prisioneiros de guerra indefesos exemplifica bem os problemas gerados pelo uso de tal "manual de cultura interior": trata-se de um "povo rude" que só cresce a partir do que pensa como necessário para si. Em Believe and Destroy, Christian Ingrao (2013) persegue com riqueza de detalhes como uma geração de intelectuais alemães participou ativamente da máquina de guerra nazista, a SS. Eles assim procederam não só através de uma "ciência combativa" e de uma doutrina fundada em princípios, mas também exemplificando através de atos concretos de violência como exterminar os "inimigos". Como o estudo de Ingrao explora profundamente, vários atores de relevância do movimento nazista foram gestados nas principais universidades alemãs da época. Eles literalmente acreditavam em seu dever de destruir, mesmo tendo sido muito bem-educados nas universidades, tendo lido e absorvido 
de modo enciclopédico grande quantidade de conhecimento. Exemplo sumário de como a barbárie que emergiu naqueles tempos não estava despida de manuais, bem como dela não se pode dizer que era propriamente inculta. Eles já sabiam o que estavam fazendo e ainda o faziam.

\section{Ética do esquecimento}

Ainda sobre a importância de lidar com o sentido a-histórico, o esquecimento e o não-saber, vale citar "Resistência à memória: usos e abusos do esquecimento público", artigo em que Andreas Huyssen, ao desenvolver o que chama de políticas do esquecimento, sugere que "A exigência moral de lembrar foi articulada em contextos religiosos, culturais e políticos, mas ninguém, a não ser Nietzsche, jamais fez a defesa geral de uma ética do esquecimento" (20I4, p. 157). Gostaríamos de, com isso em mente, retomar a crítica de Foucault à empresa enciclopédica nesse sentido relacional: só através da preservação da possibilidade de esquecer e mesmo de não-saber não nos iludimos pela promessa de felicidade que uma empresa enciclopédica que tudo quer recordar pode criar. Rudi Visker exemplifica essa posição através do interesse de Foucault pelos saberes $p s i$, pois eles "escrevem a história da condição de sua emergência não com a intenção de retomar suas origens, mas de modo a esquecer a vergonha da origem" (Visker, I995, p. I8). Assim, é na medida em que elide a relação com a existência do não-saber, com a possibilidade de esquecer, bem como não lida com os motivos da emergência da vergonha, que tal prática enciclopédica só se torna um problema para nós.

Encontramos ainda mais uma remissão esporádica à Enciclopédia em uma conferência de dezembro de 1969, cujo problema central é o de saber quais os problemas a linguística moderna introduz para o pensamento. Foucault sugere que as ciências sociais solicitam das ciências da linguagem forma e conteúdo de conhecimento exemplares. O caso citado é o Discurso preliminar da Enciclopédia, em que D’Alembert propóe que se é preciso um dicionário diverso com a forma de uma análise da língua, isso assim se dá de maneira que um monumento possa se dirigir a geraçóes futuras, permitindo-as o contato com as técnicas e os conhecimentos do século XVIII. O que, segundo a leitura de Foucault, pode ser visto como o poder de dar uma imagem, um perfil, um enquadramento da sociedade e da civilizaçáo daquele século construídos como um dicionário de palavras ( $D E \mathrm{I}$, p. 822). Encontramos o termo também em uma publicação de jornal escrita pelo autor e publicada no Brasil, onde se lê:

Assim, mesmo para mim, atualmente, as manifestaçóes da razão analítica que seria a nova filosofia - estão ainda dispersas. É desse modo que se apresenta para nós uma tentação perigosa, o retorno puro e simples ao século XVIII, tentação que ilustra bem o interesse que se guarda atualmente pelo século XVIII. Mas tal retorno é impossível. Não faremos mais a $E n$ ciclopédia, tampouco o Tratado das sensaçōes de Condillac (DE II, p. 424). 
A posição de Foucault mostra-se assim direta e simples: um pensamento que acredita na imediata transparência do discurso, que acredita retomar os postulados de uma enciclopédia para iluminar, manter completamente esclarecida a relação entre palavras e coisas, entre os saberes e os não-saberes, um tal pensamento postula um retorno que não só é impossível, como cede a tentaçôes perigosas de uma promessa de encontro singelo com o que deseja chamar de realidade, de felicidade e de beleza. Essa visão acarreta uma elisão estratégica dos riscos em nome do potencial da racionalidade. Esquece-se, porém, que a anulaçáo do que é considerado como não-saber pode ganhar proporçóes radicalmente violentas: seja através da exclusão social da loucura; da justificação enciclopédica da escravatura; do extermínio em massa de pessoas consideradas como degeneradas, ou mesmo pelo intensivo governo dos corpos que pouco tolera uma sexualidade que náo lhe pareça produtiva, incapaz de conceber uma relação com os prazeres que não se mostre ascética e disciplinada.

\section{Outra enciclopédia?}

Haveria, todavia, um segundo sentido do termo enciclopédia? Ao reler uma conferência pronunciada em 1964, despertei para essa intrigante possibilidade. Nela lemos o seguinte:

Realmente, por trás destes temas [concernentes a técnicas de interpretação], há um sonho: seria o de um dia poder fazer um tipo de Corpus geral, de Enciclopédia de todas as técnicas de interpretaçáo que pudéssemos conhecer desde os gramáticos gregos até os nossos dias. Creio que poucos capítulos deste grande corpus de todas as técnicas de interpretação foram redigidos até o presente ( $D E$ I, p. 564).

Pronunciado logo no início da conferência "Nietzsche, Freud, Marx”, elaborada à época da redação de As palavras e as coisas, esse trecho parece náo se referir ao sentido de enciclopédia aludido anteriormente. Foucault fala de um sonho que não consiste na completa reunião de nossos saberes. Ele quer estudar algo que lhes é anterior: as técnicas de interpretação. Tais técnicas consistiriam nos meios pelos quais cada época faz a ligação entre as palavras e as coisas, dando conta das outras coisas que "falam e não são linguagem" tanto quanto do que permanece inaudito no discurso. Como explicita o autor, dois tipos de suspeita são despertados pela linguagem - enquanto material dessas técnicas - a saber, a de que a linguagem não diz exatamente o que diz; e a de que "ela ultrapassa sua forma propriamente verbal", ou seja, de "que há certamente no mundo outras coisas que falam e não são linguagem" ( $D E$ I, p. 564). O sonho de uma enciclopédia desse gênero nasce digamos de alguma maneira em um gesto crítico - pois ao contrário de desejar encontrar a técnica mais geral capaz de tudo interpretar, ele deseja retomar só aquelas que "podemos conhecer". Além disso, continuaria sendo enciclopédia na medida em que 
reúne diferentes maneiras pelas quais essa relação entre palavras e coisas foi concebida ao longo do tempo. Poderíamos falar de uma enciclopédia crítica?

Náo sabemos. Em todo caso, Foucault chega a "rascunhar" alguns "capítulos" dessa "enciclopédia". É o caso de quando fala sobre tais técnicas na Grécia a partir de uma rápida alusão à allegoría e huponóia, vistas como meios pelos quais se percebe isto que não diz exatamente o que diz; e algo parecido ele diz sobre o semaínon que caracterizava essa relação de ultrapassagem dos limites verbais da linguagem — através dos signos algo mais se manifestava que não o meramente linguístico, verbal ( $D E$ I, p. 563). Após uma rápida e não aprofundada citação de termos gregos, ele retoma uma questão trabalhada por ele em As palavras e as coisas (1966): a de como semelhança, até o século XVI, teria sido uma unidade mínima de interpretação. Trata-se de um modo que aos nossos olhos pode parecer confuso: interpretar por semelhanças consiste em apresentar uma ampla rede de similitudes que aproximam signos de diferentes maneiras, quais sejam, por conveniência (convenientia), simpatia (sympatheia), emulação (emulatio), assinatura (signatura) e analogia. Através dessas formas, detalhadamente exemplificadas pelo autor em seu livro de 1966 ( $P C$, pp. 23-63) no capítulo sobre "A prosa do mundo", tudo possui algum parentesco com tudo e à técnica de interpretação em questão caberia fazer emergir, através dessas figuras, as mais diversas semelhanças entre coisas, incluídas aí as palavras. Com a crítica de Bacon e Descartes ao reinado da semelhança no interior das técnicas de interpretaçáo ( $D E \mathrm{I}, \mathrm{p} .566$ ), separam-se as palavras das coisas, através da representação, cuja enciclopédia no primeiro sentido exposto constitui melhor exemplo, uma vez que a imagem ou a palavra representam, e náo mais se confundem com as coisas.

Para Foucault, as técnicas de interpretação serão colocadas em suspeita no século XIX quando Nietzsche, Freud e Marx suscitam um novo capítulo nessa história das técnicas de interpretação. Os três pensadores teriam sido notáveis por não buscar uma origem primeira e profunda, um espaço do qual os sentidos e os signos viriam. Muito pelo contrário, eles teriam se notabilizado por mostrar como na superfície mesma do que falamos, podemos notar relaçóes interpretativas, laços produzidos, forças e jogos em causa, levando em consideração o inacabamento e a dispersão dos discursos. Tanto a genealogia em Nietzsche, a livre associaçáo proposta por Freud, quanto a análise da ideologia em Marx privilegiariam análises que interpretam o meio pelo qual as interpretaçóes são elaboradas sem propor um mergulho nas profundezas originais e universais de tempos desconhecidos, bem sem exigir uma clarificação total e irrestrita dos espaços de não-saber. Um valor moral como bem ou mal, um sonho ou um ato falho, ou mesmo um fetiche resultam já das interpretaçôes das interpretaçóes que se tem de algo. Ao invés de buscar simplesmente interpretar o mundo - como quem olha para uma flor e se pergunta, "O que é uma flor?", eles se perguntam "Por que dizemos que algo é bom ou mal?", "Por que sonhamos com isso ou com aquilo?", "Por que desejamos uma coisa da marca tal e 
não simplesmente a coisa?”. Em todos os casos, não é simplesmente a relação entre o que pensamos e um objeto, mas a maneira de interpretar que está em questáo e, consequentemente, é interpretada. Se para Freud (20I5, II, \$I4), por exemplo, o sonho seria uma realização (disfarçada) de algum desejo recalcado, nesse sentido ele já resulta de uma interpretação desse desejo. Através deste tipo de modulagem do problema, Nietzsche, Freud e Marx abririam um novo capítulo por proporcionarem interpretaçóes das maneiras pelas quais interpretamos os nossos valores, corpos e processos de produção.

Ainda, vale notar como "ponto de ruptura da interpretação" um tema importante para Foucault, citado neste texto, qual seja "a experiência da loucura". Sua relação com o assunto sugere o retorno constante de uma experiência limite que não só o impressiona como talvez o ameace, como fez a Freud, ao analisar o caso "Schreber", que sugere que "o futuro decidirá se na teoria há mais delírio do que eu penso, ou se no delírio há mais verdade do que outros atualmente acreditam” (Freud, 20Io, p. I03); bem como a Nietzsche, que foi tomado por ela ( $D E$ I, p. 57O; $D E$ II, p. II3). Para Foucault, essa ameaça contínua de poder enlouquecer sugere que a experiência da loucura desafia, uma vez que a interpretação racional se liga a discursos continuamente em mutação, que resistem sem cessar a interpretaçôes definitivas. Por que a razão estaria sempre à beira da loucura? Seria o delírio uma outra forma de razão, a ser encontrada no por vir, como Freud insinua no caso "Schreber"? Nietzsche, Freud, Marx, uma vez diante da impossibilidade de firmar definitivamente razóes, ousaram usar de um tipo específico de "violência", a saber, a de escolher uma perspectiva, sem insistir procurar a verdadeira interpretaçáo diante do que sempre oferece novas possibilidades. Eles teriam situado seus trabalhos, como 'psicólogos' no interior dessa experiência de interpretação das interpretaçóes. Nesse sentido, cito o autor:

Nada há de absolutamente primeiro a interpretar, pois no fundo, tudo já é interpretado, cada signo é em si mesmo não algo que se oferece à interpretação, mas interpretação de outros signos. [...]. Com efeito, a interpretaçáo não esclarece uma matéria a interpretar, que se oferece a ela passivamente. Ela só pode se apoderar, e violentamente, de uma interpretação já ali, onde deve subverter, revirar, quebrar a marteladas ( $D E \mathrm{I}$, p. $57 \mathrm{I})$.

Gary Gutting (1989, pp. 273-275) salienta com precisão os dilemas que essa passagem pode despertar: se entendermos esse trecho como uma defesa de que o pensamento de Foucault sugere algo excessivamente relativista, algo do gênero "só há interpretaçôes", simplificamo-lo a ponto de colocá-lo sobre o risco de legitimar críticas como a de Merquior (1985) para quem o trabalho de Foucault repousaria sobre o seguinte dilema: "Se ele diz a verdade, logo todo conhecimento é suspeito em sua pertença de objetividade; mas em tal caso, como a sua própria teoria pode garantir sua verdade?”. Gutting sugere que Foucault segue uma tradição de pensadores para os quais "não há fatos dados de modo simples, separados de conceitos" e por isso não haveria fatos ininterpretáveis. Diferente, porém, de outros neo-kantianos, ele 
sustentaria que "os limites [de nossas experiências e pensamentos] são eles mesmos produtos contingentes de nossa história". Então, seriam violentos um pouco como sugere Alexander Nehamas (1986, p. 688) em seu artigo "What an author is", "o processo de contínuo ajuste não tem fim. A interpretação termina quando o interesse míngua, não quando a certeza, ou um sentido último são alcançados”. Menos do que uma garantia racional, é grau de interesse, de atenção, de disputa que faz prevalecer certas interpretaçóes, o que por si só sugere um gesto superficial e violento diante daquilo que se interpreta.

O que os três autores retomados acabam por fazer é se interessarem por aquilo que era relegado até então por parecer superficial ou trivial. Eles acabaram por tornar o ininterpretável interessante para o momento histórico em que se situaram. Os exemplos são esclarecedores. No caso dos atos falhos, dos sonhos ou dos chistes ao estabelecê-los como objetos de análise, Freud dá dignidade àquilo que era impensável ou irrepresentável. Ele chama a atenção para importância do que era excluído, como gesto sem sentido, errado, anormal ou estranho, sem pretender-lhe uma origem primeira ou um sentido originário, sem buscar a boa ou a má interpretação para um sem número de gestos: trata-se de interpretar o que chamamos de falho, engraçado, o que chamamos de nobre, de mal, de bom, de verdadeiro. Isso, evidentemente nos coloca diante de uma tarefa infinita que talvez só se rompa pela violência das semelhanças, ou pela força de uma interpretaçáo convincente - e, quem sabe, só enquanto seu convencimento faz minguar o interesse. Daí por exemplo, a possibilidade de reinterpretar as perspectivas sobre um ato falho, um valor moral ou sobre as relaçóes de produção em uma dada época.

Poderíamos sugerir algo parecido partindo do aforismo "Nosso novo infinito", no qual lemos Nietzsche a dizer:

Até onde vai o caráter perspectivista da existência, ou mesmo se ela tem algum outro caráter, se uma existência sem interpretação, sem "sentido" [Sinn], não vem a ser justamente "absurda" [Unsinn], se, por outro lado, toda a existência não é essencialmente interpretativa - isso não pode, como é razoável, ser decidido nem pela mais diligente e conscienciosa análise e autoexame do intelecto: pois nessa análise o intelecto humano náo pode deixar de ver a si mesmo sob suas perspectivas e apenas nelas. Não podemos enxergar além de nossa esquina: é uma curiosidade desesperada querer saber que outros tipos de intelectos e perspectivas poderia haver: por exemplo, se quaisquer outros seres podem sentir o tempo retroativamente ou, alternando, progressiva ou regressivamente (com o que se teria uma orientação da vida e uma outra noção de causa e efeito). Mas penso que hoje, pelo menos, estamos distanciados da ridícula imodéstia de decretar, a partir de nosso ângulo, que só dele pode-se ter perspectivas. O mundo tornou-se novamente infinito para nós: na medida em que náo podemos rejeitar a possibilidade de que ele encerre infinitas interpretaçôes (Nietzsche, 2002, \$374). 
Nesse aforismo de A gaia ciência, Nietzsche sugere o mesmo exercício de interpretar a possibilidade de interpretaçóes, ciente da dificuldade do intelecto de fazer um autoexame. Ele assume certa condição paradoxal, qual seja, a de que não estamos em uma condição suficientemente apta para decidir se uma existência sem interpretação é absurda ou não, seguindo-se daí a necessidade de atentar ao risco da interpretação, aos valores implicados em cada uma delas. Uma vez que o "mundo", após a superação das dicotomias cristãs e utilitaristas, se torna novamente infinito, uma gaia ciência não deve rejeitar a possibilidade de que as interpretaçóes se multipliquem infinitamente. Isso não significa afirmar a impossibilidade de interpretar, e sim de que as perspectivas sejam múltiplas e seu confronto faça proliferar ao infinito esse jogo. Nietzsche parece sugerir que nossas limitaçôes não nos devem impedir de interpretar, desde que cientes que essa interpretação pode ser sucedida por outras infinitamente.

Poderíamos também recorrer ao celebre aforismo de Marx, já tão citado, quando diz que "Os filósofos se limitaram a interpretar o mundo de diferentes maneiras; mas o que importa é transformá-lo" (Marx, 20I2). Uma vez mais temos um exemplo da interpretaçáo das interpretaçóes. Marx resume sua contraposiçáo a uma atitude teórica típica de sua época, qual seja a de se limitar a estudar e interpretar o mundo sem se comprometer com a ação gerada por sua interpretação. Nesta constatação já está contida uma interpretação das interpretaçóes. Marx interpreta a atitude dos filósofos como limitada, e sugere a necessidade de "transformar o mundo", o que passa por conectar essa capacidade de pensá-lo de diversas maneiras à de agir diferentemente, alterando o "mundo", e consequentemente, as interpretaçóes usuais que dele se têm. A incitaçáo no sentido de transformá-lo sugere a possibilidade de retomar com interesse assuntos até entáo marginalizados, ressignificando os modos de produzir novas coisas e interpretaçóes infinitamente. Nesse sentido, a ênfase que Foucault confere à ideia de que a teoria já é uma prática, e que sua prática analítica também o é, pode ser vista claramente como uma retomada do problema da práxis em Marx, lançando mão de novas ferramentas. Éric Clemens nota, com razão, que Foucault não comenta a XI tese no artigo em questáo (1985, p. 199). Todavia Clemens não nota como a problematizaçáo das práticas do presente é uma constante no trabalho de Foucault, desde esse artigo até quando retomará na virada da década de I980 um texto de jornal de Kant para discutir a possibilidade de uma ontologia do presente. Assim, tal problematização objetiva suspeitar das maneiras como se concebe o mundo não só pelo gozo da constatação, como quem diz "eu bem sabia que as coisas andavam assim", mas para servir como caixa de ferramentas para sua transformação.

Através desses casos, esboçamos rapidamente como os pensadores da suspeita utilizavam técnicas que lhes permitiram interpretar as interpretaçóes. Ao abordarem as interpretaçóes através da superficialidade presente, sem recorrer a origens remotas, assumindo o caráter inacabado e infinito de suas tarefas, esses pensadores retomaram uma atitude diante da linguagem que resgata os potenciais esquecidos desde a Revolução Científica e a épistémè da representação. Análises que não cessam de se 
implicar elas mesmas em sua atividade de modo a inserir no horizonte de interpretação aquele mesmo que interpreta, expondo assim a finitude do intérprete diante da infinitude de sua tarefa.

Retomemos aquela que talvez seja a mais célebre alusão de Foucault a uma enciclopédia: o prefácio de As palavras e as coisas. Sem grandes introduçôes, cito-o:

Este livro nasceu de um texto de Borges. Do riso que, com sua leitura, perturba todas as familiaridades do pensamento - do nosso: daquele que tem nossa idade e nossa geografia -, abalando todas as superfícies ordenadas e todos os planos que tornam sensata para nós a profusão dos seres, fazendo vacilar e inquietando, por muito tempo, nossa prática milenar do Mesmo e do Outro. Esse texto cita "uma certa enciclopédia chinesa" onde será escrito que "os animais se dividem em: a) pertencentes ao imperador, b) embalsamados, c) domesticados, d) leitöes, e) sereias, f) fabulosos, g) cäes em liberdade, h) incluidos na presente classificação, i) que se agitam como loucos, j) inumeráveis, $k$ ) desenhados com um pincel muito fino de pelo de camelo, l) et cetera, $m$ ) que acabam de quebrar a bilha, n) que de longe parecem moscas". No deslumbramento dessa taxinomia, o que de súbito atingimos, o que, graças ao apólogo, nos é indicado como o encanto exótico de um outro pensamento, é o limite do nosso: a impossibilidade patente de pensar isso $(P C, \mathrm{p}$. IX).

Em uma primeira leitura, é quase inevitável que o leitor espirituoso sorria junto e graças à atitude de Foucault. Essa citação sem referência de "O idioma analítico de John Wilkins" de Jorge Luís Borges (1974, pp. 706-709) por si só é inusitada e algo impensável como epígrafe de um livro dedicado à "arqueologia das ciências humanas". Acreditar, em todo caso, que se trata só de um efeito de abertura, um fogo de artifício que nos coloca no rosto um sorriso pode deixar escapar algo do pensamento de Foucault manifesto ali.

A primeira frase constata o lugar de nascimento desse livro: no texto de Borges, a enciclopédia chinesa. Como vimos, esta se dedicaria comumente a apresentar a familiaridade entre os diversos saberes, reunindo-os e justapondo-os de modo a clarificar uma determinada ordem de discursos que elide o espaço do náo-saber. Ao propor o lugar de nascimento de seu livro sobre as ciências humanas em uma enciclopédia chinesa é seu próprio sentido que surge imediatamente ressiginificado. Essa arqueologia nasce remetida a uma enciclopédia imaginada na literatura, um tipo de não-saber. O livro nasce de um texto cujo espaço estava até então elidido, perturbando as familiaridades do nosso pensamento atual (que tem a nossa idade e geografia). Das duas expressões grifadas assinalo na primeira delas que tal enciclopédia perturba a ordem do familiar, leva a um riso de estranhamento, nos coloca diante da impossibilidade de pensarmos o nosso próprio limite, através dessa experiência taxionômica que nos parece familiar, mas não é absolutamente, e desperta para o interstício entre saber e náo-saber. Foucault sugere que diferente de sua história da loucura que perturba a imagem feita do outro, da desrazão e dos "loucos", trata-se em As palavras e as coisas de uma "história da ordem das coisas" que "seria a 
história do Mesmo - daquilo que, para uma cultura, é ao mesmo tempo disperso e aparentado, a ser portanto distinguido por marcas e recolhido em identidades" $(P C$, p. XI $)$ - feita não para reconhecer esses "Mesmos" como um enciclopedista clássico, mas para abalar a ordem que se deseja reconhecer como garantida. Ao pensar numa outra enciclopédia completamente perturbadora, Foucault levanta a possibilidade de serem nossos saberes táo perturbadores em sua capacidade de estabelecer o mesmo, quanto as imagens da loucura o são, em outro sentido.

Ele mesmo admitirá anos depois, em 1976 no Japão, numa fala que serve como contraponto a afirmação de um ocaso da literatura (Machado, 2005), que a tendência literária experimentada por Borges se contrapóe ao positivismo científico, ou noutros termos, à tendência enciclopedista presente na literatura francesa do século XIX, especialmente em Zola e Hugo. Isso porque, cito-o, "Ao descrever os saberes e as civilizaçóes [...], ele dá relevo ao peso da inquietude e da angústia que residem na civilização moderna constituída em torno desses saberes: é aí, me parece, que reside a força crítica que possui a literatura borgeana" ( $D E$ III, p. 85). Menos do que afirmar o esclarecimento irrefletido, a atitude de Borges diante do enciclopedismo habilita uma reflexão sobre o lado fantástico, estranho, não-familiar e, por isso, questionável que se atribui aos saberes de seu tempo.

Sugerir uma radical ressignificação do sentido de enciclopédia incorre necessariamente na defesa de novos sentidos de história e saber até então formulados vagamente pelos antecessores de Foucault, deixando capítulos de uma história ainda por fazer, como ele mesmo assinala em "Nietzsche, Freud, Marx". Essa vaga e "episódica" sugestáo de ressignificar a noção de enciclopédia ganha assim um sentido mais amplo, quando conectada ao quadro mais geral das pesquisas de Foucault: torna-se uma reavaliação de nossa noção de saber. Ciente dos problemas de método ensejados por seu trabalho, ele deixou assinalado nesse mesmo prefácio uma referência a uma "próxima obra" em que examinaria as características dessa nova maneira de escrever a história: a arqueologia.

Não impressiona o exemplo dado no início de As palavras e as coisas. Um texto de Borges, aparentemente irrelevante para quem deseja fazer uma história das origens das ciências humanas, surge como o lugar de nascimento de uma arqueologia proposta por Foucault. A sugestáo não me parece uma licença poética. $\mathrm{O}$ texto de Borges é visto como uma prática discursiva que colabora por contraste para a análise do que são esses saberes específicos chamados de ciência do homem. Ele ajuda a desnaturalizar nossos a priori, desestabilizar nossos saberes, a questionar nossa ontologia espontânea. Evidentemente ao proporcionar um estranhamento tal diante daquela taxionomia, ele permite compreender melhor a sugestão final de que "o homem não é o mais velho problema nem o mais constante que se tenha colocado ao saber humano" ( $P C$, p. 535). Se para os contemporâneos de Foucault, a enciclopédia chinesa poderia parecer estranha, estranhamento semelhante pode ser sentido quando compreendemos a historicidade das ciências do homem. Elas tanto quanto 
seu objeto de estudo - o homem — são "uma invenção cuja recente data a arqueologia de nosso pensamento mostra" (ibid.) não tão facilmente, como sugere Foucault, mas certamente com algum êxito. Em todo caso, podemos perceber em que medida aquele sonho de uma outra enciclopédia é realizado por Foucault através de sua arqueologia, uma vez que nela diversas práticas discursivas, tanto as consideradas pela Enciclopédia no primeiro sentido assinalado, quanto as deixadas de fora, são ambas relevantes para responder as perguntas desse novo enciclopedista.

\section{Atonalidade}

Deleuze começa seu estudo sobre Foucault sugerindo estar o novo arquivista em uma "espécie de diagonal", que torna legível "o que não podia ser apreendido de nenhum outro lugar": os enunciados. E dispara a questão: "uma lógica atonal?" (Deleuze, 1988, p. 13). Por que "atonal?" A par de considerar a hipótese do autor sobre a raridade dos enunciados, o adjetivo "atonal" remete de pronto à história da música. José Miguel Wisnik, em $O$ som e o sentido, sugere que "a música atonal está relacionada com um traço determinante do tempo que foge à experiência: o nãotempo inconsciente, enquanto tempo não linear, não ligado, não causal, tempo das puras intensidades diferenciais" (1989, p. I75). Experiência-limite dos sons, a atonalidade é caracterizada por um processo de composição no qual todas as notas ganham uma importância semelhante, preterindo a necessidade de um centro tonal, de uma estrutura harmônica ou melódica, capaz de conferir algum sentido de totalidade, ou de linearidade à composição. Trata-se de destacar as relaçóes entre as notas, mais do que o sentido que se poderia atribuir a uma delas, um tom, essa experiência fugidia que protagonizaria a direçáo do sentido.

Ainda sobre o texto de Borges, Foucault confessa que este o fez "rir durante muito tempo, não sem um mal-estar evidente e difícil de vencer”, prossegue ele

Talvez porque no seu rastro nascia a suspeita de que há desordem pior que aquela do incongruente e da aproximação do que não convém; seria a desordem que faz cintilar os fragmentos de um grande número de ordens possíveis na dimensão, sem lei nem geometria, do heteróclito ( $P C, \mathrm{p}$. XI, grifos do autor).

Dispostas em lugares tão diversos que é impossível definir para elas um lugarcomum, assim palavras e coisas parecem funcionar segundo uma lógica atonal numa desordem que exibe os fragmentos de ordem, as causalidades e linearidades que a consciência, em vão, atribui a um todo. Desordem que a pesquisa sobre o inconsciente faz emergir: o estranhamento gerado por peças como as de Schoenberg que se assemelham a esse despertado pelo texto de Borges — vieram de um outro lugar, de um outro espaço, algo estranho como a China, mas que não é consolador como uma utopia, esse lugar sem lugar real, que desde Thomas More ocupa a ima- 
ginação ocidental com sonhos para um futuro cujo espaço nunca estará completamente determinado, uma vez que as utopias estão em um plano semelhante àquele das ideias: algo irrealizável.

\section{Heterotopias}

O elemento atonal a que se refere Deleuze, Foucault o denominou de heterotopia:

As heterotopias inquietam, sem dúvida porque solapam secretamente a linguagem, porque impedem de nomear isto $e$ aquilo, porque fracionam os nomes comuns ou os emaranham, porque arruínam de antemão a "sintaxe", e não só aquela que constrói as frases - aquela, menos manifesta, que autoriza "manter juntos" (ao lado e em frente uma das outras) as palavras e as coisas. Eis porque as utopias permitem as fábulas e os discursos: situam-se na linha reta da linguagem, na dimensão fundamental da fábula; as heterotopias (encontradas tão frequentemente em Borges) dessecam o propósito, estancam as palavras nelas próprias, contestam, desde a raiz, toda possibilidade de gramática; desfazem os mitos e imprimem esterilidade ao lirismo das frases ( $P C, \mathrm{p}$. XII).

Podemos escutar a leitura dos textos de Foucault ou de Borges, conferir um sentido a seus sons, atribuir-lhes uma gramática. No entanto, a atonalidade das heterotopias corresponde a impossibilidade de dar um nome comum, uma vez que a desordem que esses textos pretendem despertar desnaturaliza uma ligação transparente e direta entre palavras e coisas. As utopias correspondem à maneira de pensar que cria uma linha reta entre as palavras e as coisas, projetando essa linha em direção ao futuro. Na fábula, sintaxe e semântica convergem para permitir a emergência de um sentido moral, semelhante àquele do discurso ordenado de uma homilia, de uma cidade planejada ou de uma declaraçáo de guerra - em todos os casos, uma racionalidade, uma gramática organiza os espaços que estão por vir. Nestes casos, um espaço maravilhoso é imaginado, com vastas avenidas, belos jardins, famílias e profissóes educadas, batalhôes enfileirados no front, todos segundo princípios que poderiam muito bem constar em uma enciclopédia. Mas como bem notam os autores do Dicionário de Alternativas, uma utopia pode se tornar facilmente uma distopia, e vice-versa (Parker et al, 2007, p. 80; p. 300). Uma distopia constitui um espaço em alguma medida catastrófico em que nem o escritor, nem o leitor desejariam viver, é uma espécie de anti-utopia. Os autores lembram que ambas, utopias e distopias, refletem os contextos em que foram escritas. Poderíamos ler a famosa obra de Thomas More, Utopia (20I7), como uma forma de distopia se considerarmos o tipo de racionalidade ali em voga, cujos sonhos incluem puniçóes extremas, proibiçóes sexuais e de gênero, a busca por um caráter uniforme, por um regime completamente hierárquico. Isso a um tal ponto, que não seria difícil imaginar More a ler Admirável Mundo Novo (1993) de Aldous Huxley e pensar ser um bom regime para garantir a felicidade, estabilidade e segurança de pessoas bem obedientes. De modo que a distância que separa ou aproxima o ambiente distópico do ambiente utópico 
depende do que se chama de racional e de como os valores se moldam em torno de tal racionalidade.

A atonalidade das heterotopias inquieta: o propósito de fazer uma enciclopédia soa risonho, estranho, estrangeiro; os mitos surgem desfeitos nas Mitológicas; a "Biblioteca de Babel" reúne obras o suficiente para fazer com que seu usuário se perca entre seus corredores; as dicotomias encontram seu lugar na história e o estranhamento diante de um tempo e espaço inconscientes perturba.

Ao pensar sobre os espelhos, na conferência "Outros espaços", Foucault salienta as diferenças entre utopia e heterotopia. Sobre o espelho como lugar da utopia, ele sugere:

No espelho, me vejo onde não estou, em um espaço irreal que se abre virtualmente atrás da superfície; estou distante, lá onde não estou, um tipo de sombra que dá a mim mesmo a minha própria visibilidade, que permite me olhar lá onde estou ausente: utopia do espelho ( $D E$ IV, p. 756).

Como numa fábula, ou numa sinfonia tonal, notas, moedas e medalhas se multiplicam em uma casa de numismática, tanto pelo capital que fantasticamente valem, quanto pelo mundo de espelhos que as refletem. De todas as partes e tamanhos, cores e texturas, seu valor de exposição ali, entre os reflexos do brilho de uma luz branca, se mostra em seu valor de culto. Senhores de todas as idades, jovens pela rede, um monitor ligado no centro da loja e um leiláo: todos atentos aos valores dos valores. Não se trata de uma convenção pela transvaloração genealógica de valores morais. São as moedas que desafiam a aritmética. Duas notas de um real valem ali mais de dois reais e póem em questão a própria realidade do dinheiro. Ali, torna-se evidente que o dinheiro não é só um mero instrumento representativo do valor do trabalho, deixou de ser um símbolo usado para o valor de troca, para criar uma realidade própria de valores, na qual o objeto vale por si e multiplica em si mesmo o seu valor. Numa casa de numismática, as utopias sem lugar se instalam, aparecem e permitem ver que os valores passaram a ocupar lugares fantásticos, pois isso que se mostra valer não está mais lá da mesma maneira, se projetando maior e mais valioso do que supostamente ele seria, através do tempo e de um ideal de história. As moedas ali ganham dimensóes imateriais, são valores que se dão ao olhar onde eles já não estão mais presentes, longe das relaçôes de troca por trabalho. Ali o irreal se forja real, um real que se dobra, se multiplica e se transforma em muitos reais.

Os espelhos que cobrem as paredes das vitrines refletem e ilustram essa multiplicação fantástica. Os objetos nele dobrados fazem ver uma vez mais o valor, que se antes era literalmente notado em algum canto do pequeno expositor, já não está mais lá, na imagem com a sombra presente, agora com frente e verso, e que de todo modo vemos, quando olhamos para as múltiplas perspectivas de uma mesma moeda, cada vez mais plena no espaço imaginado. No espelho, temos a cara e a coroa, as duas faces e uma síntese imaginária. Nas casas de numismática, não só as moedas 
estão refletidas e multiplicadas pelos espelhos, como refletem os sonhos de uma riqueza absoluta, abstrata e duradoura.

Foucault não vincula o espelho à utopia. É só um modo de olhar através dos espelhos que gera um espaço utópico, pois o espelho, como ele ressalva:

É igualmente heterotopia, na medida em que o espelho existe realmente, e que ele possui, no lugar que ocupo, um tipo de efeito retroativo. É a partir do espelho que me descubro ausente no lugar em que estou, pois me vejo lá. A partir desse olhar que de algum modo se lança sobre mim, do fundo desse espaço virtual que é o outro lado do vidro, eu retorno e recomeço a lançar meus olhos sobre mim mesmo e a me reconstituir aí onde estou. $\mathrm{O}$ espelho funciona como uma heterotopia nesse sentido que ele torna possível este lugar que ocupo, no momento em que me vejo no espelho, ao mesmo tempo absolutamente real, em relaçáo com todo espaço que o envolve, e absolutamente irreal, já que ele é obrigado, para ser percebido, a passar por aquele ponto virtual que está lá longe ( $D E$ IV, p. 756).

A adversativa apagada que inicia esse trecho — um "mas" por nós apagado ressalva a ambiguidade do espelho. Sim, é lugar sem lugar, lugar das utopias, mas é igualmente o lugar das heterotopias, e isso na medida em que ele existe, não é só projeção de uma imagem: ele ocupa um espaço que é diferente do meu. $\mathrm{O}$ espelho retroage sobre mim. É preciso perceber nesse caso que o espelho projeta sempre algo de nós que em geral náo percebemos e que se faz preciso notar. Traço que resiste, insiste em chamar a atenção para aspectos de si que, pela utopia de uma imagem criada, foram relegados para um segundo plano. $\mathrm{O}$ espelho devolve o nosso olhar mesmo, com toda a energia por ele possuída, seja de angústia, alegria, preocupação, tristeza, atenção, admiração ou desprezo. Ele é fisicamente o lugar onde algo de si aparece refletido por um espaço outro, em outros espaços, recortando, reduzindo, planificando ou enquadrando, exagerando, como nos casos distópicos/utópicos, mas também e notadamente ampliando as perspectivas em que podemos nos ver de modos diferentes.

\section{Uma intervenção}

Em maio de 1974, a I7 ${ }^{\text {a }}$ Câmara correcional de Paris condenou o diretor da revista Recherches por "ultraje aos bons costumes" graças ao número de março de 1973, intitulado Grande enciclopédia dos homossexuais - Três bilhöes de perversos, um número coletivo escrito por pessoas ligadas ao tema, mas não sexólogos. A condenação havia se dado "não por causa do assunto", mas "pelas palavras e fotografias empregadas" que consistiam, sendo o juiz, numa "exibição libidinosa de uma minoria perversa". O julgamento confirmou ainda a apreensão e destruição de todos os números ( $D E$ II, p. 536). No calor da situação, Foucault publicaria uma intervenção pública discutindo os problemas despertados pela atitude do tribunal. Perguntava-se como integrar a sexualidade na luta política. Ao fim, ele sugere: 
Há séculos reina toda uma política do corpo. Com efeito, desde os séculos XVII e XIII , o corpo humano foi, por vezes, usado, esquadrinhado, encerrado, "espartilhado" como força de trabalho. Esta política consistia em extrair o máximo de forças úteis para o trabalho e o máximo de tempo útil para a produção. Atualmente, a questáo que se póe é esta: será ou não possível recuperar seu próprio corpo, e também o corpo dos outros — com todas as relaçóes que isso implica - por outra coisa que não o uso da força de trabalho? ( $D E$ II, p. 537).

A intervenção vem em defesa de uma enciclopédia incompleta e censurada, apreendida e tomada como infame. A sumária elaboração do problema político em questáo na citação acima se manifesta em torno de um verbete preciso: o corpo. Nem só de palavras se faz uma enciclopédia: há práticas que preterem um discurso específico para se constituírem enquanto práticas. Os trabalhos que Foucault desenvolverá fizeram essa ligaçáo - a das práticas que usam os corpos sem exigir um discurso definido e específico, e por isso, não-discursivas, ao lado daquelas que falam sobre os corpos entre tantas outras coisas, as práticas discursivas (AS, p. 75; $D E$ I, p. 686; $D E$ IV, pp. 578-584). Os corpos disciplinados passaram a obedecer uma política de extração do máximo de tempo e forças úteis para a produção e o trabalho, e a questão que o autor levanta desafia esse utilitarismo incorporado pelo nosso dia-a-dia. Isso de tal modo que náo nos deixa esquecer da suspeita levantada por Nietzsche na primeira dissertaçáo de A genealogia da moral sobre como um instinto de rebanho moldou a maneira como se entende o bom enquanto útil, não egoísta e desinteressado, que acabou por excluir e mesmo abominar o que achava não ser útil (Nietzsche, 1998, \$2). A enciclopédia apreendida póe em litígio uma noçáo de corpo que obedece a essa moral. Recuperar o corpo corresponde à capacidade de poder usá-lo para além dos limites da força de trabalho, emancipando-o em outras direçóes tais como a de uma sexualidade menos dirigida à simples reprodução. $\mathrm{O}$ problema político que a censura dessa enciclopédia levanta é também este: pode o corpo vivenciar outras maneiras de encarar a sexualidade que náo aquela dirigida à força de trabalho? É possível governá-lo de outra maneira? Daí a sugestão de que:

Foi essa luta pelo corpo que fez com que a sexualidade se tornasse um problema político. É compreensível, em tais condiçôes, que a sexualidade dita normal, ou seja, reprodutora da força de trabalho - com tudo o que ela supóe como recusa de outras sexualidades e também de assujeitamento feminino queira se mostrar normativa. E é também normal, no movimento político inclinado à recuperação dos corpos, que se encontre movimentos pela liberação da mulher, assim como pela homossexualidade masculina ou feminina (DE II, p. 537).

A intervenção é sutil, porém eficaz. Náo se trata de condenar a sexualidade reprodutora da força de trabalho. É compreensível que ela queira sempre se mostrar como normal, que ela deseje governar o modo pelo qual os corpos são governados. O que Foucault questiona é o próprio limite da normalidade. Por que entáo outras práticas, que não essas, não são normais? Por que não encarar também como normal 
uma sexualidade menos presa à passividade e recato femininos ou a maneiras alternativas de vivê-la? Defender essa enciclopédia através de uma nova perspectiva sobre a genealogia da moral é intervir em práticas cotidianas por um corpo que ainda não se sabe qual é, por um pouco de possível para os corpos, para suspeitar do que se acredita natural ou normal, questionando-o e expandindo-o tanto quanto os verbetes se mostrarem possíveis. Lutar, enfim, por uma enciclopédia diferente pode ser lutar por algo mais do que palavras e interpretaçóes.

\section{Referências bibliográficas}

BOLIVAR, G. (20I7). "Uma arqueologia das ciências humanas: As palavras e as coisas", In: Sapere Aude, vol. 7, n. I2, Belo Horizonte, PUC Minas.

Borges, J. L. (1974). Obras completas. Buenos Aires: Emecé.

CAstro, E. (2009). Vocabulário de Foucault. Belo Horizonte: Autêntica.

D’Alembert, J. le R. \& Diderot, D. (20I5). Enciclopédia, Dicionário razoado das ciências, das artes e dos ofícios. 5 vol. Tradução de P. P. Pimenta e M. das G. de Souza. São Paulo: EdUNESP.

Deleuze, G. (1988). Foucault. Tradução de C. Martins. São Paulo: Brasiliense.

ERIBOn, D. (1990). Michel Foucault. Tradução de H. Feist. São Paulo: Companhia das Letras.

Foucault, M. (1977). O Nascimento da Clínica [NC]. Tradução de R. Machado. Rio de Janeiro: Forense universitária.

Foucault, M. (1978). História da loucura na Idade Clássica [HL]. Tradução de José Netto. São Paulo: Perspectiva.

Foucault, M. (1994). Dits et écrits [DE] (I-IV tomes). Paris: Gallimard.

FouCault, M. (2004). Vigiar e punir: nascimento da prisão [VP]. Tradução de R. Ramalhete. Petrópolis: Vozes.

Foucault, M. (2006). A arqueologia do saber [AS]. Tradução de L. Neves. $7^{\text {a }}$ ed. Rio de Janeiro: Forense Universitário.

FouCAult, M. (2007). As palavras e as coisas. [PC]. Tradução de S. Muchail. $9^{\text {a }}$ ed. São Paulo: Martins Fontes.

FouCault, M. (2008). Segurança, território e população [STP]. Tradução de E. Brandão. São Paulo: Martins Fontes.

Foucault, M. (2009). A ordem do discurso [OD]. Tradução de L. Sampaio. São Paulo: Loyola.

FOUCAUlT, M. (20IO). O governo de si e dos outros [GSO]. Tradução de E. Brandão. São Paulo: Martins Fontes.

FouCAUlt, M. (20II). Leçons sur la volonté de savoir [LVS]. Paris: Gallimard.

FouCAUlT, M. (20I4). Aulas sobre a vontade de saber [AVS]. Tradução de R. Abilio. São Paulo: Martins Fontes. 
Foucault, M. (20I4). Do governo dos vivos [GV]. Tradução de E. Brandão. São Paulo: Martins Fontes.

Foucault, M. (2016). Subjetividade e verdade [SV]. Tradução de R. Abilio. São Paulo: Martins Fontes.

GuTting, G. (1989). Michel Foucault's Archaeology of Scientific Reason.Cambridge: Cambridge University Press.

HaN, B. (1998). L'ontologie Manquée de Michel Foucault. Grenoble: Jerome Millon.

HuXley, A. (1993). Admirável Mundo Novo. Tradução de L. Vallandro e V. Serrano. São Paulo: Globo.

Huyssen, A. (20I4). "Resistência à memória: usos e abusos do esquecimento público", In: Culturas do passado-presente. Rio De Janeiro: Contraponto.

IngRaO, C. (20I3). Believe and Destroy: Intellectuals in the SS War Machine. Tradução de Andrew Brown. Cambridge: Polity.

MARX, K. (2OI2). “Teses sobre Feuerbach”, In: As armas da crítica: antologia de pensamento de esquerda. Tradução de R. Enderle, N. Schneider e L. C. Martorano. São Paulo: Boitempo.

Marx, K. \& Engels, F. (2010). Manifesto Comunista (I848). Tradução de A. Pina e I. Jinkings. Sáo Paulo: Boitempo.

Merquior, J. G. (1985). Michel Foucault ou o niilismo de cátedra. Rio de Janeiro: Nova Fronteira.

More, T. (20I7). Utopia. Tradução de M. M. Gouvêa Júnior. Belo Horizonte: Autêntica.

Nitezsche, F. (2002). A gaia ciência. Tradução de P. C. de Souza. São Paulo: Companhia das Letras.

NitezsCHe, F. (2003). Segunda Consideraçâo Intempestiva: da utilidade e desvantagem da história para a vida. Tradução de M. Casanova. Rio de Janeiro: Relume Dumará.

Norberto, M. (20I2). "Sartre e Foucault: reminiscências do presente”, In: O que nos faz pensar, n. 3I. Rio de Janeiro: PUC Rio.

SOARES, J. D. Itinerários sobre linguagem via Foucault. Dissertação de mestrado. Rio de Janeiro: PUC Rio, 2014.

SouzA, M. das G. (2015). "Círculo dos conhecimentos", In: Enciclopédia, ou Dicionário razoado das ciências das artes e dos ofícios. 5 vol. São Paulo: Unesp.

VISKER, R. (1989). Michel Foucault: Genealogy as Critique. Londres: Verso.

WisniK, J. M. (1989). O som e o sentido. São Paulo: Companhia das letras.

Wittgenstein, L. (2009). Investigaçôes Filosóficas. Tradução de M. G. Montagnoli. Petrópolis: Vozes. 